\title{
La caiguda de Felicià Piquer, bruixot processat per la Inquisició de València (1669-1673)
}

\section{The fall of Felicià Piquer, wizard processed by the Inquisition of València (1669-1673)}

\author{
Albert Toldrà i Vilardell \\ albert.toldra@uv.es \\ Universitat de València
}

\begin{abstract}
Resum: Felicià Piquer és un modest bruixot de la ciutat de València, amb no merescuda fama de sacatesoros; com tots aquests, té algun coneixement de màgia i sobretot molta xerrameca i poca vergonya, tot i que la seua característica personal és que empra les seues operacions màgiques per a abusar sexualment de dones, cosa que acabarà portant-lo a la presó reial i finalment als calabossos del sant Ofici; al seu procés inquisitorial, entre els anys 1669 i 1673 es descriuen les seues darreres aventures, habilitats, tècniques $i$ instruments i modus operandi, així com la seua trista fi, delatat fins i tot pels seus companys de presó.
\end{abstract}

Paraules clau: Inquisició, bruixeria, processos inquisitorials, sacatesoros

\begin{abstract}
Felicià Piquer is a modest wizard from the city of València, with no deserved fame of sacatesoros (treasures finder); like all of them, has some magic knowledge and above all he is chatty and shameless, although his personal characteristic is that he uses his magical operations to sexually abuse women, which will lead him to royal jail and finally to the jails of the Santo Oficio (Holy Office, Inquisition); in his inquisitorial process, between 1669 and 1673, his latest adventures, abilities, techniques and instruments and modus operandi are described, as well as his sad ending, denounced even by his prison companions.
\end{abstract}

Keywords: Inquisition, witchcraft, inquisitorial processes, sacatesoros (treasures finder)

\footnotetext{
* Aquest article s'inclou en les recerques de l'equip de treball del projecte d’investigació «Biografías marginales: violencia, sexo, género e identidad. Edición y análisis de fuentes documentales valencianas de la Época Foral» (PGC2018-097011B-I00) del Ministerio de Ciencia, Innovación y Universidades del Gobierno de España.
}

DATA PRESENTACIÓ: 16/03/2019 ACCEPTACIÓ: 20/05/2019 • PUBLICACIÓ: 23/06/2014 
Albert Toldrà i Vilardell. La caiguda de Felicià Piquer, bruixot processat per la Inquisició de València (1669-1673)

En aquest article farem un colp d'ull en un interessant procés del tribunal del Sant Ofici de València, el de Felicià Piquer, sacatesoros. ${ }^{1}$ El 18 de març del 1669 Feliu Vila, notari, es presenta motu proprio davant els inquisidors de València, Juan González de Texada i Juan Casteldases, per tal de denunciar Felicià Piquer, pintor, ara tancat a les presons reials de les torres dels Serrans, per haver violat dues xiques; també hi és empresonada Paula Pisà, madrastra d'una de les víctimes, la qual, convençuda que a sa casa hi havia un tresor soterrat, havia fet des de nadal excavacions infructuoses («no descubría moneda, antes salía agua»), fins que va decidir cridar Felicià, home reputat que sabia trobar tresors. Tot plegat, afirma Feliu, ha provocat un notable escàndol a la ciutat. Acaba contant als inquisidors que ell va ser el notari que va fer l'escorcoll en la casa de Felicià, on va trobar coses que «le ha parecido tocar a este Santo Oficio», com ara dos caps de llangardaix i alguns papers amb invocacions diabòliques (f. 2r.-3v.), proves jurídiques que passaran a mans de la Inquisició quan aquesta reclame la transferència del procés, una volta sentenciat Felicià per la justícia reial.

Obrim un parèntesi: a València, entre els segles XVI i XVIII la creença en tresors soterrats constitueix una autèntica obsessió, i la tècnica per a trobar-los és un dels capítols de rigor en tots els llibres de màgia. ${ }^{2}$ Tresors generalment atribuïs als «moros»-amb la possible base real d'alguna troballa casual-i que d'acord amb la tradició medieval basada en la profecia de Daniel $^{3}$ d'atribuir a l'Anticrist -al dimoni, al capdavall- un vincle amb les riqueses enterrades o submergides, solen estar protegits per determinats encantaments de marcat caràcter oriental, amb princeses o donzelles, turcs, negres, moros... Extraure el tresor no és qüestió de sort o de paciència: cal desfer prèviament l'encantament, i aquí és on apareix la figura de l'expert, el sacatesoros, habitual protagonista de molts processos inquisitorials. Personatges ben curiosos, amb més o menys coneixements de màgia,

1 Arxiu Històric de la Universitat de València (AUV), secció Varia 44/5. Faig servir, per a referir-me al protagonista d'aquest article, el terme «bruixot», no en un sentit estricte històric d'«home que practica el maleficium» - d'altra banda també almenys conegut per ell, com veurem-, sinó en un sentit ample, com a home que realitza pràctiques màgiques, endevinatòries, etc, qualificades pels inquisidors com a supersticions.

També hem d'explicar l'ús del castellà com a llengua processal en una València prèvia al decret de Nova Planta, i en què el sistema judicial reial funciona amb normalitat, com veurem, en català. La Inquisició és la primera -i durant quasi dos segles l'única- institució que al nostre país empra oficialment el castellà, des de la dècada del 1520. Així doncs, els secretaris del Sant Ofici realitzen filigranes de traducció simultània per escriure en castellà unes declaracions fetes -una gran part- en valencià.

2 Al també bruixot Joan Miquel Rius (AUV, Varia 43/5), mallorquí, la Inquisició de València li troba l'any 1657 , entre altres llibrets de màgia relligats al procés, almenys dos de destinats a trobar tresors; un porta com a títol «De los Thesoros» (f. 52r.), i conté els capítols: «1-Si hay Thesoro donde se presume. 2-De qué naturaleza es el thesoro. 3-Si lo hallará el querente. 4-En qué parte o lugar de cassa se hallará». L'altre s'anomena «Exorcismos y conjuros para lugares donde haya espíritus o demonios, que se ha de hazer por un Sacerdote» (f. 121r.). Malgrat el títol, és un altre manual de sacatesoros.

3 Dan 11, 43: «Et dominabitur thesaurorum auri et argenti, et in omnibus pretiosis Aegypti». Tema repetit en la predicació de sant Vicent Ferrer: «Lucifer et omnes dyaboli servient sibi, et omnes thesauri auri et argenti, lapidum preciosorum, etc., sibi per demonies aperientur et presentabuntur et ille distribuet cuilibet sibi adherere volenti» (Ferrer 2009: f. 51r.). I també: «dize la santa Scriptura que todo el oro e la plata e piedras preciosas que se perdieron en la mar serán a su mandamiento del Antichristo» (Ferrer 1994: 537).

SCRIPTA, Revista internacional de literatura i cultura medieval i moderna, núm. 13 / juny 2019 / pp. 175-193 ISSN: 2340-4841 · doi:10.7203/SCRIPTA.13. 15480 
Albert Toldrà i Vilardell. La caiguda de Felicià Piquer, bruixot processat per la Inquisició de València (1669-1673)

nigromància o alquímia, amb una facúndia capaç d'ensarronar i sobretot amb molta barra, com és el cas que ara ens ocupa. ${ }^{4} \mathrm{El}$ que resulta singular és que sol tractar-se de pobres diables, gent lumpen que viu en la misèria, fet que deuria ser la prova fefaent de la seua ineficàcia com a sacatesoros.

Però, tornem al cas que ens ocupa. Quatre dies més tard Feliu Vila torna a presentar-se als inquisidors per completar la seua declaració anterior: ha escorcollat ara una arca de Felicià, que conté altres papers sospitosos; es remet a la còpia de l'auto de la justícia reial, que n’inclou la llista, documents que presenta als inquisidors (f. 6r.-v.). Com sabem, a l'Antic Règim conviuen diferents sistemes judicials -reial, senyorial, eclesiàstic, inquisitorial...- que se solapen al mateix territori i sobre les mateixes persones. D'aquests documents, el primer, amb data de 15 de març, conté la llista dels objectes i escrits trobats a casa de Felicià «en lo carrer que va de la plasa del Abre a les Quatre Cantonades de mossén Sorell», actual de Sant Tomàs. Qui fa l'escorcoll i el document és Josep Vilar, porter del governador, per ordre de Francesc Díez, assessor de causes criminals del portantveus de governador. Entre altres llibres i escrits, el porter hi troba alguns de bruixeria, $\mathrm{i}$ «en un caixonet de dit escritori fonch atrobat, en un paper embolicats, dos caps de dragó» (f.4r.-5r.).

I amb data del 19 de març, una altra llista, ${ }^{5}$ elaborada per un altre porter del governador, Joan Creus, del contingut de l'arca esmentada per Feliu. Hi troben diversos escrits i alguns objectes sospitosos, com ara «un troset de ferro o aser, en algunes gotes de sera verda», així com «un tros de saronet de Criatura, ab lo qual naixen les criatures». Aquest sarronet o còfia cefàlica, conegut en italià com camicciola i en francès com coiffe (d'on ve l'expressió être né coiffé, nàixer amb sort), és una pell que roman adherida al cap d'alguns xiquets en nàixer, $i$ té un gran poder màgic freqüentment emprat per les bruixes (Lacarrière 2000: 138; Ginzburg 1966). En l'enumeració dels inquisidors l'objecte metàl lic resulta ésser «un pedacito de cobre», els alarmants caps són «de dragones o ranas», i el sarronet, «el pedacito de Zurroncillo con que nacen los niños». S'hi adverteix, però, que els objectes, com que no han pogut ésser integrats a la sumària, han quedat dipositats al secreto -la secretaria- del tribunal (f. 71r.).

Els escrits, bruts, plegats i rebregats, elaborats per diverses mans amb lletra vacil lant i de vegades il legible, sí que són relligats al procés, i consisteixen en la típica barreja d’oracions heterodoxes populars, encaminades a aconseguir amor o maleficium, invocacions diabòliques o altres salms i conjurs. L'habitual còctel de supersticions i bruixeria diabòlica, inclòs a l'Index librorum probibitorum. ${ }^{6}$

4 Vegeu l'estudi, força interessant, que fa Julio Caro Baroja del cas de Nicolás de Oliver, condemnat pel tribunal de Toledo per sacatesoros, nigromant i invocador, i per posseir llibres prohibits - entre ells la Clavícula (AHN, Inq. de Toledo, lligall 88, 14) (Caro 1992: I, 412 i s.).

5 Document despenjat del procés i arxivat ailladament, amb la signatura AUV, Varia 25/6.

6 «Regla IX. Se prohíben todos los escritos sobre las ciencias ocultas que sirven para la invocación del demonio y todos los escritos de astrología judiciaria, que pretenden dar a conocer lo que depende de la libertad del hombre y de la fortuna». Índex de Quiroga (1583). Citat per Martínez 1984: 817. Vegeu també Bologne (1993: 166 i s.), Boscà (1991: 67), Caro (1992: I, 42) i Kieckhefer (1992: 66). 


\section{Albert Toldrà i Vilardell. La caiguda de Felicià Piquer, bruixot processat per la Inquisició de València (1669-1673)}

En destaquem tres documents: en primer lloc, dues oracions ben conegudes, amb diverses variants en aquest temps. La primera és la de santa Juliana (f. 73r.), en una barreja de castellà i llatí no comprès, per a trobar tresors enterrats, «me dexes ver lo que ai debaxo de tierra, oro, plata, perlería, piedras de valor», així com per esbrinar si aquestes riqueses són encantades i vigilades per «guardas» màgics. L'altra és la de santa Helena, un conjur amatori en versió curta -ja que n’hi ha de més farragoses-, on s'hi conta la llegenda del descobriment de la vera creu, vagament relacionada amb la versió de la Legenda aurea, ${ }^{7}$ amb fórmules màgiques intercalades $-\mathrm{i}$ en fem notar la vacil lació en el génere de l'invocant, tan aviat masculí com femení. ${ }^{8}$ I un altre sortilegi, també amatori i notòriament nigromàntic, amb invocació explícita d'uns quants dimonis; la fórmula demana a la santa l'execució del maleficium, la impotència de l’home estimat («lo encortes de cojón, de pijón») amb altres dones que no siguen la interessada.?

\footnotetext{
7 Varazze (1480: f. 59v. i s.; 1977: 464) i Vorágine (1982: 287).
}

8 «Dichosa y bienaventurada santa Elena, ija sois de rey y reina y vos reina de por sí, madre del rey Constantí, levantastes una mañana y el mar rompistes y pasastes: así rompa yo el coraçón de fulana; y con tres judíos [...] top[as] tes; así tope yo con el que deseo, con fulana. -Judíos -les digistes-, enseñadme la crus de nuestro señor Jesuchristo. Y los judíos dixeron que no lo sabían. Con la tribulación y pena que la gloriosa y bienaventurada tenía de allar la cruz de nuestro señor Jesuchristo, mandóles encarselar, y con tres días que no les diesen de comer ni bever. Así esté fulana sin comer ni bever asta que yo alleg[ue] a ella. Y al cabo de los tres días dixo el más ansiano de ellos:-Gloriosa y dichosa santa, sacadnos de la prisión y dadnos bien de comer y de bever, que no[sotros] os diremos dónde está la crus de nuestro señor Jesuchristo. Después de bien comido y bien bevido, tomaron tres picos y se fueron al monte Tabor, y la santa con ellos, y cavaron y la crus del mal ladrón sacaron, y dixo la gloriosa santa que no era aquella. Pasaron más adelante y cavaron, y la santa con ellos. La crus del buen ladrón sacaron, y dixo la gloriosa santa que no era aquella. Pasaron más adelante y cavaron, y la santa con ellos, y la tierra tembló a más que temblar, y la crus de nuestro señor Jesuchristo sacaron. Por conoser quala era, por estar la dichosa santa dudosa, pasó por allí un cuerpo muerto y ensima de la crus le pusieron: luego resusitó. Conosió la dichosa y bienaventurada santa que era aquella. Pasaron más adelante y los tres clavos que nuestro señor Jesuchristo fue enclavado les allaron [...] el pueblo alegró. Así se alegre mi coraçón y en tristesca el coraçón de fulana asta que se vea conmigo. Y el un clavo le dio a su ijo, el emperador Constantino, porque en qualquier batalla que entre sea vençedor y no vencido. Así vensa yo el coraçón de fulana y que no me vença a mí. El otro le arroxó en el mar en el golfo de León, porque todas las naves de qualquier modo de navegasión que sea tenga(n) buen puerto. Así lo tenga yo en lo que busco con fulana. Y el otro le guardó para sí, para emprestar a viudas, casadas, donsellas, fronteras, cantoneras, desdichadas. Yo soi uno d'ellos; no pido que me lo deis, si no que me lo emprestéis, y en el coraçón de fulana lo inquéis incado y atravesado, que no pueda estar en cama ni en casa ni en campo si no conmigo y así, dichosa santa, si lo avéys de aser, asedme un señal. Finis. (Una altra mà:) Cógilo a la ventana entre onse y dose de la noge es relas(?)» (f. 74r.).

9 «Toma una redomilla nueva de vidrio, que te costará tres dineros, y pondrás en ella lo que se sigue. Primeramente, 3 dineros de aguardiente, 2 dineros de vino muy bueno, 1 dinero de asufre molido, 1 dinero de alún molido; la metat de media onsa de timiama; 1 dinero y aún no de sal. Y puesto todo esto dentro la redoma por su orden como está escrito, con mucho tiento, sin mover los materiales, la tomarás y, poniendo la boca de la redomita junto la tuya, dirás este conjuro por tres veses, mostrando mucha fuer[ç]a: "Yo te conjuro por San Pedro, por San Pablo; yo te conjuro por Satanás, por Barrabás, por la mujer de Gaifás, por el príncipe de todos, te conjuro por el marqués de Villena con toda cavallería, yo te conjuro por dona María de Padilla con toda su guaparía, y te conjuro por el diablo conxuelo (sic, per Cojuelo), que es buen amigo, que es más lijero que el mensagero, que vaia en donde está T. y me lo traiga enamorado, apacionado, amartelado en amor y voluntad mía, que no me lo dexes comer ni bever ni dormir ni reposar ni sozegar, y en esto te ruego que me lo encortes de cojón, de pijón y la parte [...] del coraçón, que no pueda fornicar viuda, casada, 
Albert Toldrà i Vilardell. La caiguda de Felicià Piquer, bruixot processat per la Inquisició de València (1669-1673)

Tornem al procés. El 23 de març del 1669 és portada al tribunal una de les víctimes, Josepa Mandingorra o Bendingorra, de setze anys i natural de Requena, la qual després d'haver estat acollida pel pare d'òrfens, la institució municipal que es feia càrrec dels menors desemparats, ara viu -imaginem que com a criada- a casa de Pere López, guanter. L'escenari del drama és la casa de Joan Pont, saboner del carrer del Carme, on Josepa treballava de criada; farà una densa i esfereïdora declaració. Comença contant que una veïna va dir a Paula Pisà, la dona de l'amo, que havia sentit que a sa casa hi havia un tresor; l'ama, immediatament convençuda, fa cridar Felicià per traure'l, perquè «sabía sacar tesoros». El bruixot, en efecte, detecta el lloc on és amagat el tresor, al soterrani de la casa, i per enviscar-los a tots fa un típic truc de màgia: ompli una fiola-redoma- de vidre amb aigua, hi aboca unes pólvores i fa repetir als presents l'oració de santa Juliana, que ell va llegint; llavors Felicià diu que ha de mirar l'ampolla una verge, i adreçant-se a Josepa opina «que esta no estaría doncella», opinió desmentida immediatament per la indignada declarant.

A continuació, i ací ve la primera mostra de com el bruixot aprofita les seues activitats màgiques per abusar de les dones, li fica el paper amb l'oració escrita pel coll, entre la camisa i la carn, i fa que Josepa mire l'ampolleta; ella hi veu unes coses de colors, que Felicià afirma que són les perles del tresor. Paula, l'ama, i Magdalena, la seua fillastra, també fan la prova diverses voltes; en una d'elles Paula hi veu «un turco y unos animalotes», gràcies al fet que és prenyada de set mesos, cosa que augmenta la seua capacitat vident, segons el bruixot. En una altra ocasió, Paula diu que a l’ampolla se li apareix «una viuda con un librito en la mano, y una doncella muy polida, toda vestida de blanco». Mentre fan aquests experiments, van cavant al lloc del tresor, i Felicià fumiga el lloc amb unes pòlvores que crema i escampa mitjançant un tubet. En una ocasió, Felicià mana a Josepa que es pose ajaguda de bocaterrosa al forat, mentre ell se li asseu damunt i li diu que mire si veu sortir-ne res; llavors ella troba dos escarabats, que el bruixot pren i s'emporta a casa per esbrinar si són dimonis. I així és: a la vesprada els diu que els escarabats s'han volatilizat, o siga que sí, que eren els esperits que vigilaven el tresor.

donsela, ramera ni de cualquier estado que sea si no es a T. Y si me estima y me quiere bien, te estés entero, y si no, que te rompas el cuello". Dicho tres veses este conjuro, ya tendrás prevenido unas ascuas de fuego bien encendidas, y pondrás sobre ellas la redoma, dixiendo al ponerla lo que se sige: "No te dé redomita, si no el coraçón y les entranes de T., que no puga estar ni sosegar ni reposar ni conversar ni comer ni bever asta que me venga buscar, dándome quanto tuviere". Y estando hirviendo tomarás tres pajuelas y, ensendiendo la una, la pegarás fuego a la boca de la redoma (...) y acabándose la llama, tomarás las tres paxuelas y les pondrás dentro la redomita, disiendo: "No son paxuelas, si no tres saetas que le atraviesen el coraçón y las entranas, que no pueda comer ni bever ni dormir ni sosegar ni reposar asta que me venga a buscar apacionado, enamorado, amartelado en amor y voluntat mía, dándome cuanto tuviere". Advierte que quando fueres a mercar la timiama, irás disiendo: “Timiama voi a mercar por mi bien, mas no por mi mal”, a lo menos 3 veses; y otras tantas quando la estuvieren pesando. Al poner los ingredientes en la redoma, si te parece, puedes desir lo que sigue: "Yo te conjuro, lumbre, por todos los elementos del infierno, todo lo que pudiere agora en ti me lo concedas por todo el tributo del infierno. Y principio por el aguardiente: yo te conjuro, aguardiente, que eres la fortalesa morta por la fortalesa d'ella. Yo conjuro, vino, por el poder que eres de Barabás. Yo te conjuro, asufre, por el sainete que eres del infierno. Te conjuro, alún, pues con el asufre serás el de sainete, tanbién para el infierno. Ti digo, timiana, la que los onbres 1[] amas, yo te conjuro para que así 1[1]ames y tires al coraçón, sentidos y entranas de T., para que me dé luego quanto tenga, sin que yo le pueda, haga quanto quiera y finido monte. Te conjuro, sal, por príncip Lusbel, pues eres el gusto tal"» (f. 75r.-76v.). 
Albert Toldrà i Vilardell. La caiguda de Felicià Piquer, bruixot processat per la Inquisició de València (1669-1673)

Al cap d'uns dies de cavar i mirar la fiola, Felicià sentencia que el tresor només el trobaran «con lágrimas de doncellas, y deshonrándolas, conociéndolas él carnalmente». A més a més, caldrà emprar diferents espelmes beneïdes: de la Candelària, la «María de las tinieblas» i un ciri pasqual, una estola sacerdotal -que Paula demana amb una excusa a mossén Sales, de Sant Miquel- i aigua beneïda de tres parròquies, la qual replega la mateixa Josepa, de Sant Miquel, Santa Creu i Sant Joan. Aconseguit tot això, durant quinze dies, amb les espelmes enceses i després d'abocar l'aigua beneïda al forat del tresor, Felicià hi assota Josepa i Magdalena amb uns cordons «en las nalgas, levantadas las faldas, a cada una a solas», per fer-les plorar. Recordem ací que a l'Antic Règim el càstig físic i aquest tipus d'assots són força freqüents, tant en pràctiques disciplinàries com penitencials (Foucault 1975; Ryley 2006; Toldrà 2017). També les lliga amb l'estola, l'una a l'altra, mentre parla amb els guardians del tresor: «-Salid, salid de aquí, y, si no queréis salir, hazed rayas en la pared!». I efectivament, apareix a la paret un número 4 a l'inrevés, i el bruixot exclama: «-A, el cabrón que me ha puesto aquí un número quatro, que es señal que no me quiere dar el tesoro menos que no quite la virginidad a dos donzellas!». Aquests guardians, diu, són «tres demonios, que el uno es simple, el otro sordo y el otro discreto». Felicià convenç amb sorprenent facilitat les dues xiques, Josepa i Magdalena, que «se dexasen deshonrar conciéndolas carnalmente para que dicho tesoro saliesse». La segona li respon que només si els seus pares ho accepten, i Paula, la seua madrastra, li diu que sí, i a Josepa, la criada, que ella la dotarà amb mil ducats a canvi de la virginitat, quan tinguen el tresor.

I arribem al fatídic dia de sant Blai, el 3 de febrer del 1669. Aquell dia Felicià, amb el consentiment de Paula, baixa amb les noies al soterrani, encén les espelmes i escampa pel forat l'aigua beneïda i «orines de esta y de dicha Paula, su ama, que las havía prevenido las tuviessen juntas en una caçuela», elements imprescindibles per a l'extracció del tresor; llavors assota les joves al cul amb un ganivet amb el mànec negre, de pla, i

\begin{abstract}
(...) hizo que esta se hechasse en el suelo al lado de dicho hoyo, boca abaxo, con las faldas arromangadas por detrás, y sobre esta hizo que se hechasse la dicha Madalena, también boca abaxo y las faldas por detrás levantadas, y él con los calzones desatacados y con el miembro viril armado se puso sobre la dicha Madalena y la puso entre las piernas su miembro viril, y quería que apretasse las piernas; y estuvo breve espacio de esta manera y luego hizo que esta se pusiesse encima de la dicha Madalena en la misma forma que havían estado, y se hechó también sobre esta, poniéndola su miembro viril entre las piernas, y esta se sintió mojadas las piernas de lo que havía hechado del miembro dicho Piquer. Y lo mesmo le dixo a esta dicha Madalena, que havía ella sentido quando se puso sobre ella por detrás, y lo vieron porque se huvieron de limpiar con las camisas. Y dixo que esto lo havía hecho porque no quería deshonrarlas (f. 11v.-12r.).
\end{abstract}

Tanmateix, diu després el bruixot, no hi ha cap altra manera de trobar el tresor que «deshonrando a esta y dicha Madalena». Llavors, el mateix matí, fa baixar primer la fillastra de l'ama al soterrani, on estan una mitja hora, i després baixa amb Josepa: 


\title{
Albert Toldrà i Vilardell. La caiguda de Felicià Piquer, bruixot processat per la Inquisició de València (1669-1673)
}

\begin{abstract}
(...) la levantó las faldas por delante, y teniendo dicho Piquer su miembro viril armado, se le metió a esta por su natura, penetrándola y haziéndola mucho dolor. Y haviendo acabado, sacó su miembro y limpió a esta con su camisa de la sangre, que le salió arta de aquella parte (f. 12r.-v.).
\end{abstract}

En acabant, Felicià diu a Josepa que guarde el secret del que han fet, que no és pecat (aquesta afirmació, en la declaració, és subratllada pels inquisidors: herètica), i que si ho diu, fins i tot al confessor, el tresor «se desvanecería». En eixir, davant les tres dones el bruixot diu que no pot desencantar el tresor, que necessita un llibre que li han de portar de França, «y con esto se fue dicho Piquer y no bolvió más a dicha casa». Finalment Josepa declara que més tard Magdalena li va dir que amb ella havia fet el mateix, i que mentre la forçava, Felicià s'adreçava als guardians del tresor: «-Dadme el tesoro!». Josepa no signa la declaració perquè no sap escriure, cosa habitual al segle XVII i més en el cas de les dones (f. 9r.-13v.)

El mateix dia 23 de març, a la vesprada, és duta al tribunal l’altra víctima de Felicià, Magdalena Pont, de quinze anys, filla de Joan Pont i de la seua primera dona, Agustina Serrana. Ella ara és a sa casa amb son pare, que ha restat al marge de l'afer. Fa la mateixa narració in extenso que Josepa, que acabem de veure; però n'esmentem alguns detalls que completen o alteren la versió. Segons Magdalena, Josepa, la criada, insistia molt - «hizo grandes instancias»- a l'ama per a que buscaren el tresor; en la prova de la redoma, Josepa i Paula hi veien «una sierpecica y montón de perlas y una tinaja»; la serp, interpretada per Felicià, representa «una donzella encantada»; Magdalena, en canvi, potser per por davant els inquisidors, assegura que mai no va veure res a la fiola. Felicià l'havia assotada perquè plorara, per tal de desencantar la donzella, a la qual també «la havían levantado las faldas y la havían azotado para hazerla entrar». Així, Magadalena va jaure damunt un banquet, mentre ell, «levantándola las faldas por detrás, la azotó en las nalgas con unos cordeles que llevava y la dió unos azotes porque dixo que havían de ser seis, y esta lloró aunque no era mucho el dolor de los azotes». Més tard, el dia de sant Blai,

\footnotetext{
(...) tomando la estola el dicho Feliciano, las ligó con ella por el cuello juntas, haviendo hecho que la dicha Jusepa se tendiesse boca abaxo en el suelo y esta encima della, boca abaxo, y el dicho Feliciano, levantóle a esta las faldas por detrás, el qual se hechó sobre esta, y sintió que le fregava con su miembro viril entre las piernas, y se limpió después de haverse subido arriba: y luego que passó esto, hizo dicho Feliciano que se mudasen, poniéndose esta debaxo y la dicha Jusepa encima d'esta, boca abaxo entrambas, para lo qual las desató y bolvió a atar con la dicha estola, y él se hechó encima de la dicha Jusepa haviéndole levantado las faldas por detrás (...) con un cuchillo que la parece tenía el mango negro las dio en las ancas como azotándolas, dándolas de llano con él dos o tres golpes a cada una.
}

Després d'això, és quan Felicià la viola:

(...) la dixo que se arrodillase y pusiesse las manos en el suelo, y la dixo que apartase las piernas, y esta lo hizo assí, y, haviéndola arromangado, se arrimó a esta y la puso su miembro 


\section{Albert Toldrà i Vilardell. La caiguda de Felicià Piquer, bruixot processat per la Inquisició de València (1669-1673)}

viril armado en la natura d'esta; y él azía fuerza por penetrarla y esta sentía mucho dolor al tiempo de penetrarla. Y porque la havía dicho que no diesse vozes, esta se tomó el avantal y le mordía. Y sintió como que a esta le corría de aquellas partes una cosa muy caliente, no sabe si era sangre.

El bruixot també li encomana el secret, i li diu que això «sólo lo hazía por bien, que era por desencantar la mora que estava en el tesoro y no tenía crisma, para que tuviesse crisma, y que la baptizarían quando saliesse». Magdalena acaba dient que ha declarat el mateix davant la justícia reial, i per ordre del jutge «la reconocieron a esta dos comadres para ver si estava doncella, y haviéndola reconocido dixeron que no lo estava». Magdalena tampoc sap signar el document (f. 15r.-18r.).

La vesprada del 4 d'abril del 1669 es presenta a la Inquisició un rector, mossén Ginés Belenguer, jesuïta i qualificador del Sant Ofici. Aquests qualificadors són una mena de tribunal d'experts en teologia, que assessora els inquisidors en qüestions de fe, qualificant la gravetat dels delictes dels acusats. Mossén Ginés ve en nom de Josep Angost, presoner a les torres dels Serrans amb Felicià, a contar el que li ha referit: resulta que Josep havia acompanyat en una ocasió Felicià, prop d'Albal, amb la intenció de desenterrar tresors, i entre altres sospitosos manejos - una cistella amb fioles, un pentacle o cercle d'invocació diabòlica dibuixat a terra- el bruixot s'havia posat a sobar el cos d'una dona que els acompanyava. Renyat aleshores per Josep, Felicià li va contestar

(...) que no estrañase la fuesse palpando toda, porque ya sabía que con aquellos tactos ofendía a Dios y que eran pecado, pero que los hazía porque a ellos acudían luego los enemigos, y acudiendo los havía de atar con aquel círculo, y, visto esto, el dicho Angost arrojó la sesta de las redomas por parecerle mal el modo de sacar el tesoro con semejantes diligencias.

Llavors, segons la narració que ens fa arribar mossén Ginés, Josep es va tombar a descansar, i de sobte el va despertar Felicià: «-Mira que está aquí el rey sobre nosotros!», i en efecte, Josep va veure llavors «grande muchedumbre como de ministros del rey con armas de fuego encaradas azia nosotros», amb el natural espant (f. 20r.-21r.).

Dos dies més tard, aquest testimoni, Josep Angost, és dut al Sant Ofici, a petició seua; declara davant dels inquisidors González i Casteldases que és obrer de vila de València i ara presoner a les torres dels Serrans. Una nota al marge de l'inquisidor Marmanillo, sense data, però del moment de les ratificacions -cap a finals del 1671-, ens informa que Josep ha mort, per la qual cosa no podrà ratificar aquesta declaració. Ha demanat audiència per denunciar Felicià; afegeix al relat de mossén Ginés com va conéixer el bruixot: un dia, fa poc més d'un any, va veure com de la casa de davant, al carrer de Renglones, treien terra, i en preguntar el veí, Josep Meseguer, li va dir que buscaven un tresor soterrat. Dirigint l'excavació hi havia un home -Felicià, és clar-, que portava una fiola plena d'aigua i va fer que la miraren dues xiques, primer una tal Joana, i després una germana del Josep Meseguer, anomenada també Josepa. Aquesta digué que no hi veia res, Felicià va assegurar que 
Albert Toldrà i Vilardell. La caiguda de Felicià Piquer, bruixot processat per la Inquisició de València (1669-1673)

«havía de ser muy virgen para que pudiesse ver algo en la redoma», i llavors sí, Josepa hi va veure «unos como borregos y como toros y perros».

Com que no trobaven el tresor, Felicià va dir que ho deixaren estar, que ja en tenia a la vista un altre, prop de Picassent. Els presents -Josep Angost, el declarant, i Josep Meseguer- li van dir que l'acompanyarien, i efectivament hi anaren, amb un altre home anomenat Joan i la Joana esmentada. En arribar al lloc, esperaren a la nit per a no ser vistos, $i$ aleshores Felicià va treure un troç de ciri (que segons li va dir Josep Meseguer era fet «de cevo de hombre») i la fiola; es posaren a cavar, i al cap de molta estona el bruixot va encendre el ciri, llençà unes pólvores al recipient amb aigua i va fer que Joana hi miràs: «dixo que veía el tesoro, y que encima d'él estava una cadena, de oro hecha, enroscada como una serpiente». Continuen cavant i no troben res, és clar; Joana -sembla que conxavada amb Felicià- afirma «lo apartavan los enemigos», és a dir, els dimonis; llavors Josep, ja cansat i pensant que li prenien el pèl, «que era todo embeleco», agafa la fiola i la llença. Després, s'estira a dormir una mica; és aleshores quan Felicià el desperta, i Josep, «estando despierto, vio muchos bultos como de hombres con escopetas encaradas hazia este», i ell s'alça $i$ agafa una escopeta que havia dut per si de cas, moment en què desapareixen les misterioses figures. Significativament, Josep no esmenta ni el pentacle ni els tocaments a la dona (f.22r.-23v.).

Aquest mateix matí del dia 6 d'abril torna a presentar-se -segurament ha acompanyat Josep Meseguer- mossén Ginés Berenguer. Ve ara en nom de Paula Pisà, també presonera a les torres dels Serrans, per comunicar als inquisidors el seu desig de declarar quan puga, ja que en aquest moment està a punt de parir. Paula ha expressat a mossén Ginés que ho va fer tot per cobdícia i per «lástima que no se perdiesse el alma de una negra encantada, que no estaba bautiçada» -la donzella embruixada amb el tresor. O siga, que continua creient en aquestes coses, o almenys les posa com a excusa dels seus actes; $i$, ni més ni menys que davant dels inquisidors! Al marge del text, un apunt diu que mossén Ginés ha comunicat, el 22 de maig del 1669, que Paula Pisà ja ha parit i es troba recuperada i que vol «descargar su conciencia», davant els inquisidors (f. 24r.).

Un nou personatge apareix al tribunal, el dia 10 d'abril. Es tracta de fra Pere Pont, dominic del convent de Llombai i germà del saboner Joan Pont. En aquesta primera declaració, de les diverses que farà, conta com la seua cunyada, Paula, li va dir feia temps que creia que hi havia un tresor enterrat a la casa, i llavors fra Pere li suggerí que ell coneixia un home, Felicià, del qual havia sentit a dir que «andava acompañado de algunos bandidos, buscando dineros ocultos por algunos montes». El frare el porta a casa del seu germà i el bruixot diu que sí, que el tresor és «muy en la mano». Fra Pere se'n va al seu convent, i al cap de vint dies torna a València, on veu que la criada, Josepa, ha cavat un forat al soterrani, però a fra Pere, diu, tot això no li fa gens de gràcia, ja que Felicià havia assegurat que el tresor era fàcil de treure, «a lo mucho estaría a cinco palmos de ondo», i ja s'ha vist que no és així. Ell, però, se’n tornà al convent, fins al mes de gener passat (f. 29r.-30r.).

Un mes després, el 10 de maig del 1669, mossén Pere torna a la Inquisició, alarmadíssim, per desmentir la brama que corre per València: 


\title{
Albert Toldrà i Vilardell. La caiguda de Felicià Piquer, bruixot processat per la Inquisició de
} València (1669-1673)

\begin{abstract}
(...) que por la ciudad se dize que el dicho Piquer se ha disculpado cargando a este, y diziendo que este tiene la culpa de haver desonhorado este por su persona, conociendo carnalmente a Madalena Pont, doncella, sobrina d'este y hija de Joan Pont, su hermano, y a Jusepa N., criada de dicho Joan Pont y de Paula Pisà, su muger, también donzella, que ambas tendrán de edad de catorze a quinze años, y también ha dicho dicho Piquer, según este ha oydo dezir, que este le dio unos papeles para sacar el tesoro (f. 46r.-v.).
\end{abstract}

És tot fals. Felicià els havia assegurat, a ell, a la seua cunyada Paula i a les xiques, que «él era hombre honrado, que nadie donde entrara se quexaría d'él, y era ministro del Santo Oficio de la Inquisición». Aquesta darrera afirmació, subratllada pels inquisidors: és una mentida evident i perillosa, un delicte. Fra Pere reconeix ara que, tot i no agradar-li l'operació, va ajudar en l'excavació, traient cabassos de terra del soterrani, i que quan Felicià va lliurar a Paula la fiola, «que por estar preñada vería si havía en dicho puesto tesoro», ella li digué que des d'aleshores «veía visiones», per la qual cosa el dominic li va aconsellar que se'n desfés. Tot això no ho havia confessat en la seua primera declaració, per haver-se trobat «turbado» (f. 46r.-47r.).

Sí que devien haver-se escampat els fets, perquè el 28 de juny acudeix a declarar sobre Felicià, espontàniament, un altre testimoni, Joan Lacomba, rober d'origen francés. Al marge hi ha un apunt posterior que informa que Joan «se havía ydo a Francia». Deu fer un any -declara-, Felicià els va dur a ell i a un tal Miguel, home ja gran, a la desembocadura del Túria, a buscar un tresor que hi havia, ja que aquest Miguel assegurava que li ho havia dit «un moro (estando él cautivo en Argel)». En trobar-se al lloc indicat, Felicià empra, per determinar el punt exacte, el que semblen unes vares de saurí, «y las varillas se inclinavan azia la parte donde se entendía estava dicho tesoro». Com que el bruixot vol excavar-hi a la nit, per a no ser vist, assenyalen el lloc i se'n van. Aquella nit hi tornen, acompanyats de Jaume Lagresa, sabater de vell, al Tossal, i d'una dona prenyada; i per verificar si el tresor és encantat, Felicià la fa mirar la redoma, i ella diu veure-hi «una como cabeza de puerco». Mentre la dona observa l'aigua, el bruixot «la metía las manos debaxo las faldas a la muger, y en los pechos», perquè així el dimoni els lliuraria la moneda, acudint al pecat. Una altra volta trobem Felicià emprant la màgia per a la seua satisfacció sexual. En acabant, el bruixot ofereix a Joan i a Jaume que «si no eran parientes de la dicha muger bien la podían también tocan;; però ells s'hi neguen.

Encara més: Joan declara que Felicià empaitava la seua dona, Lluïsa. Li havia dit que tenia «una mala planeta», perquè l'havien d'acusar d'un furt «y la darían cien azotes por ello». Per evitar-ho, Lluïsa havia d'anar a casa del bruixot, on aquest li propinaria els assots, $\mathrm{i}$ amb això la planeta restaria anul lada. Ja comencem a copsar la planeta de Felicià. També li havia oferit a Lluïsa un beuratge per al seu marit, que així «la adoraría y querría mucho»; li havia demanat cabells -no ho diu, però segurament es tracta de pèls púbics, molt emprats en la màgia amorosa-, però ella no li'ls havia donat; i li havia enviat també una fioleta amb aigua que contenia un paperet, una «cedulita» de la qual fa Joan lliurament als inquisidors. El testimoni conta com va trobar-la a casa, per la qual cosa «tuvo un gran disgusto con su muger» i va anar a confessar-se amb mossén Calaforra, a l'església del Carme, el qual li va recomanar que vinguera a la Inquisició a contar-ho tot (f. 34r.-36r.). 
Albert Toldrà i Vilardell. La caiguda de Felicià Piquer, bruixot processat per la Inquisició de València (1669-1673)

Una setmana més tard, el 6 de juliol, és citada a declarar la dona de Joan Lacomba, Lluïsa Gausions, natural de Xàtiva i de vint-i-vuit anys -que també, en anotació al marge, se n’ha anat a França. Lluïsa conta als inquisidors l'encalç màgico-eròtic a què la va sotmetre Felicià; li va anunciar que al seu carrer hi hauria una baralla -cosa que va ocórrer-, i també li va endevinar que ella tenia «una señal en el vientre, parda»; per això pensà que el bruixot tenia poders. I en fi, feia un any, també li va dir

\footnotetext{
(...) que tenía una señal en el anca, parda, y que la quería ver, y para ello la levantó las faldas y la miró la anca, y la dixo que tenía la señal que havía dicho, y se la besó, y la dixo a esta que esta diligencia de besarla la anca era para adivinar la planeta d'esta, y la dixo que fuesse un día a su casa sola y la diría la planeta que tenía, pero esta no fue sola, si no acompañada, y por esto dixo que no se lo dezía (f. $37 \mathrm{v}$.).
}

Després narra Lluïsa l'episodi dels assots, revelant una profunda credulitat, ja que reconeix que «aunque esta se inclinó a admitir los azotes más de mano suya que del verdugo, (...) no lo permitió». També li va dir Felicià que Joan, el seu marit, o un dels seus cunyats, punxaria Lluïsa «con una aguja de cabeza envenenada» $\mathrm{i}$ que ell la guariria, però això no havia passat. I finalment la redoma per a que el seu marit i els seus cunyats «la quisiessen bien», però ella no l'ha emprada, tot i desar-la a casa, fins que el seu marit la va trobar i se la va endur (f.37r.-38v.).

El següent testimoni contra Felicià serà un altre company de presó, Mateo Mauricio San Juan, torner nascut a Saragossa i empresonat a les torres dels Serrans, el qual havia vingut espontàniament, el 16 de setembre. Conta com un dia, a la presó, Felicià li va demanar si a la seua terra hi havia molts corbs, perquè «tenía propriedad, el Cuervo, de coxer una yerba la qual rompía el yerro». Mateo, disgustat amb la conversa, es va apartar. Altra volta, conversant sobre un llibre de màgia anomenat la Clavícula de Salomó, Mateo va dir que «estava prohibida por el Santo Oficio de la Inquisición», i Felicià va respondre que era cert, «pero que dichos Inquisidores se valían d'ella para lo que les dava gusto» (f. 39r.-v.). En efecte, el Salomó bíblic esdevé a l'edat mitjana nigromàntic, i se li atribueix falsament, des del segle XIV, aquesta famosa Clavícula, una síntesi de màgia astrològica i diabòlica, amb influència de la cabalística jueva, evidentment perseguida per la Inquisició (Caro 1992: I, 159168; Klaniczay 2001: 953).

El 14 d'octubre del 1669, per fi, Paula Pisà, de trenta-quatre anys, ja recuperada del seu part -un xiquet, com li havia anunciat Felicià- $\mathrm{i}$ presonera a les torres dels Serrans, demana audiència i fa, davant els inquisidors, una llarga i interessant narració dels fets. Comença contant que va demanar al seu cunyat, fra Pere Pont, com podrien esbrinar si hi havia un tresor a sa casa, i com Felicià els ho va confirmar. Segueix amb la història de la fiola i les oracions de santa Juliana. Després indica que quan Paula hi va mirar, diu, va veure-hi «como un bulto blanco», una dona, segons el bruixot, «que estava guardando el tesoro». En altra ocasió, Paula veu al recipient «como un guzanico», que per a Felicià «era una sierpe, que se havía convertido en ella, dicha mugen»; per desencantar la dona cal treure el tresor. En el transcurs de les excavacions al soterrani havien aparegut a la paret unes lletres que deien, interpretades pel bruixot, 


\title{
Albert Toldrà i Vilardell. La caiguda de Felicià Piquer, bruixot processat per la Inquisició de València (1669-1673)
}

\begin{abstract}
(...) que en aquel tesoro estava una hija de un turco y la madre d'ella, y que una mano que estava allí pintada, que pedía venganza, y que un moro havía conocido carnalmente tres vezes a la mora que estava allí, y que por esso su padre la havía enterrado allí, y que esta havía de hazer lo mismo con su marido, y que quando estuviesse en acto carnal con él tres vezes, tuviesse en su mente, esta, las tres vezes que lo hizo el moro, haziendo cuenta esta y pensando en que el moro la conocía carnalmente a esta (f. $42 \mathrm{v}$.).
\end{abstract}

Però a Paula això no li va agradar gens, ja que era pecat. Felicià li assegurà que «él no hazía cosa que fuese pecado ni tenía necessidad de confesarse d'ello, porque no era pecado», afirmació subratllada al text pels inquisidors. Llavors, també fra Pere va intimar Felicià que «mirasse no hiziesse cosa no devida, porque él era religioso de Santo Domingo, y tocante a la Inquisición». Una autèntica premonició; tanmateix, tots els presents sabien amb què jugaven: la bruixeria era competència, tot i que no exclusiva, del Sant Ofici. Felicià els va tranquil litzar, afirmant que «él era familiar del Santo Oficio», frase també subratllada en la declaració. Els familiars de la Inquisició eren un cos de col laboradors laics voluntaris, que gaudien d'importants privilegis i immunitats i fer-se passar per un d'ells era un greu delicte, perseguit pel mateix Sant Ofici.

Paula afirma la seua innocència en el que ella creu que és la culpa principal: només es va assabentar de les violacions de la seua fillastra Magdalena i la seua criada Josepa «después de estar ya presa», i que abans «no supo nada d'esto». Això no sembla cert: segons la declaració de Josepa, Paula no sols ho sabia, sinó que les va animar a prestar-se als desitjos del bruixot. Paula, ja condemnada benignament- per la justícia reial a desterrament de la ciutat de València per dos anys, té por ara que la Inquisició li agreuge la pena; però l'abús a dues xiques no és res que interesse el Sant Ofici, en tot cas molt menys que una invocació al diable: ells jutgen el Felicià bruixot, no el violador. Paula acaba demanant al tribunal misericòrdia i «piedad de sus yerros, que sólo han procedido de simplicidad y mucha ignorancia». En efecte, no sap signar la declaració, i la ratifica immediatament ad perpetua, «porque se havía de yr a cumplir el destierro». Però quan en torne encara podrà, el 23 de novembre del 1671, fer una segona ratificació (f. 41 r.-43r.).

Van passant els mesos i el 18 d'abril de l'any següent, 1670, torna a presentar-se voluntàriament per tercera vegada- davant els inquisidors el cunyat de Paula, fra Pere Pont, en el que serà el darrer testimoni d'aquest procés. Expressa que vol declarar el que «por miedo y turbación» havia ocultat a les altres compareixences: que tenia amistat amb Felicià i que el va acompanyar en tres excursions a Llombai per desenterrar tresors, «moneda del tiempo de los moros», amb la coneguda parafernàlia de fiola mirada per dones, vares de saurí («Varas, yo os conjuro en el nombre de nuestro señor Jesuchristo, nuestro redemptor, que me digáis la verdad: ¿este tesoro dónde está?») i excavacions infructuoses (f. 31r.-33r.).

El següent document, amb data 25 d'octubre del 1670, és la qualificació dels fets; a petició dels inquisidors González i Casteldases, els qualificadors fra Cristòfol Abellà, agustí, fra Francesc Calaforra, carmelita, mossén Joan Baptista Ballester, ardiaca de Morvedre, i el paborde mossén 
Albert Toldrà i Vilardell. La caiguda de Felicià Piquer, bruixot processat per la Inquisició de València (1669-1673)

Joan Tomàs examinen, punt per punt, la sumària; determinen finalment que tot plegat constitueix «superstición divinatoria sacrílega» (f. 48r.-53r.). A continuació - cronològicament, ja que és el document que enceta el procés-, en un escrit sense data, l'inquisidor fiscal, Hermenegildo Ximénez Navarro, presenta la seua acusació preliminar contra Felicià, que ha comés terribles delictes contra la fe. ${ }^{10}$ Per tant, sol licita als inquisidors que l'acusat siga traslladat de les presons reials a les secretes (f. 1r.).

En efecte, el 29 d'octubre els inquisidors ordenen la detenció de Felicià, per a la qual cosa «se envió recado» al regent de la Reial Audiència, demanant-ne el trasllat "por causa de fe». El regent l'envià, a la vesprada, acompanyat de quatre algutzirs i el nunci, a les presons secretes, on va ser lliurat a Ambrosio Castelló, l'alcaid (f. 55r.-v.). Deduïm per la foliació del procés que ací manca un quadern -folis 56 al 63-, que devia contenir les tres primeres monicions al reu, amb les seues primeres declaracions.

Ve a continuació l'acusació formal de Marcelo Mateu, secretari en funcions de fiscal, sense data i ben detallada (f. 64r.-77r.), contestada a mesura que li va sent llegida per Felicià (f. 77v.-87v.), en dues tongades, la segona el dia 7 de novembre del 1671. Intercalarem ací algunes de les acusacions i répliques, que al text van separades, per a fer-ho comprensible. En general, Felicià negarà gran part de les acusacions. Així, a l'inicial, d’haver comés delictes contra la fe de superstició, Felicià diu que no, «porque no a tenido intención de obrar cosa mala». Nega també la curiosa acusació d'emprar fumigacions en l'excavació per invocar el dimoni: «es falso, sólo se acuerda que solía tomar tabaco de humo en el puesto donde se cavaba». Reconeix haver lligat les dues xiques amb una estola $i$ haver-les assotat, però amb molta barra diu que ho va fer

\begin{abstract}
(...) porque se lebantaban las faldas para que este las desflorase, porque decían que la dicha ama se lo aconsejaba que lo hiciesen, y este las dava con un cordel azotes porque se baxasen las faldas y se onestasen, y por esta causa era el açotarlas, y no por otra (f. 78r.).
\end{abstract}

El fiscal també descriu les violacions, tot i que això no pertany a la jurisdicció del Sant Ofici: «desflorando sin temor de Dios nuestro señor a dichas dos donzellas». Però Felicià també nega haver-les penetrat, malgrat que les joves ho volien («las instancias que le hicieron las dichas doncellas, de que las conociese carnalmente»); només hi va accedir per «evadirse de ellas», i, lluny de consumar el coit, sols va acostar «su miembro viril en sus partes verendas, sin penetrarlas, diciendo este que con aquello bastava para sacar el tesoro, y que no era menester desflorarlas, con que no las desfloró». Quant a l'afer de la planeta de Lluïsa Gausions, Felicià ho reconeix, però, o recorda malament el nom (li diu Anna), o es tracta d'un cas repetit; el bruixot confessa que -cosa que ella havia negat- «dio a la dicha muger unos açotes en las nalgas, levantadas las faldas, con un cordel».

10 «escándalos malsonantes, temerarios» (si bé no són proposicions formalment herètiques, s'hi assemblen); «de vana observancia» (superstició); «amatoria» (màgia amorosa); «divinatoria» (endevinació mitjançant nigromància); «sacrílega y heretical, con pacto implícito y explícito» (es refereix a pacte amb el dimoni); «invocación y comercio con el demonio, con sospecha veemente de culto a él (...) supersticiones, y en algunas de ellas comforma heregia» (f. 1r.).

SCRIPTA, Revista internacional de literatura i cultura medieval i moderna, núm. 13 / juny 2019 / pp. 175-193 ISSN: 2340-4841 · doi:10.7203/SCRIPTA.13. 15480 
Albert Toldrà i Vilardell. La caiguda de Felicià Piquer, bruixot processat per la Inquisició de València (1669-1673)

Ens assabentem ara pel fiscal que Felicià ja havia estat interrogat per supersticions l'any 1652 -reincident, doncs-, i que aleshores, en el moment de recitar el Credo, «dixo que se le cubría el corazón (...) y se dexó caer en el suelo, temblando mucho rato, como sin sentido». El deixaren anar, però en el procés actual, diu el fiscal, s’hi acumula aquella causa. El bruixot respon que ignora per què l'havien detingut en aquella ocasió, i explica que patia «mal de coraçón». En el punt següent, Felicià acaba d'ésser processat i condemnat per la justícia reial, el dia 11 d'agost del 1670 (el procés jurídic inquisitorial s'activa en aquell moment), a rebre cent assots «por las calles públicas y acostumbradas de esta ciudad», i a «que sirviese de remero forçado, sin sueldo ni paga, en las galeras de su magestad por tiempo de diez años». Felicià replica que és innocent i que ha apel lat a la Reial Audiència.

Tot seguit el fiscal enumera i exhibeix davant els inquisidors els sospitosos objectes i escrits trobats a casa de Felicià, «instrumentos de que se valía este reo para sacar tesoros y hacer bevidas amatorias y otros maleficios». En primer lloc, un salpasser que, segons el bruixot, és «un hisopo para la pila de el agua bendita». El segon objecte, «dos cabeças de dragones», que el bruixot diu que són de granotes i medicinals. ${ }^{11} \mathrm{El}$ tercer, el trocet de coure tacat, forma part d'una mostra que ell i un tal Jeroni Armengol confeccionaven «con diferentes ingredientes para hacer blanco el cobre y que tome el color de la plata, y los ingredientes son salitre, rasura de bota, solimán y açogue». Quant al sarronet «con que nacen las criaturas», un estri inequívocament bruixeril, afirma que «lo alló en una bolsa, y la oración de san Julián y otros papeles, que todo estava junto en la bolsa, y se la halló cerca de el Ospital General», i que no ho ha fet servir.

Pel que fa als escrits, Felicià continua espolsant-se'n: d'una fórmula màgica en llatí, diu que «se le dio a este para que se le guardara el dicho Lorenço, criado de Botavo», i que serveix per a protegir dels enemics, però que tampoc no l'ha emprada mai. Quant a l'oració de santa Juliana -que ell anomena «de san Julián», possiblement per no comprendre el femení llatí sancte Iuliane-, emprada per a trobar tresors, era a la bossa esmentada, així com la fórmula de la redoma, «para hacer bevidas amatorias y maleficios». De l'altra oració que hem vist, diu que «es una oración de santa Elena, que a este le llevaron a su casa, no se acuerda quién».

Presentada l'acusació, els inquisidors interroguen novament Felicià. Li demanen si en cap ocasió «se siguieron los efectos» de les seues conjuracions i invocacions; ell diu que no. També si feia invocacions «para que se le apareciese y hablase el demonio, y en qué forma o modo havía de ser»; contesta que de cap de les maneres no ha invocat mai el maligne ni encara menys se li ha aparegut. Després li pregunten si ha «echo o tenido» pacte amb el dimoni, «tácito o expreso», cosa que ell sembla no entendre: «explicósele uno y otro»; ell ho nega. Els pactes diabòlics són, des de la invenció

11 «Dixo que son dos cabezas de ranas, las quales tenía este para tomarlas si le retentaba el mal de coraçón, porque es una reçeta que trae el libro de los secretos de Don Alexos Piamontes. Y también porque son buenas para que, tostadas y echas polvos las ranas, y mezcladas con aceyte de averse freído güebos, untándose con ello, haçe nacer el cabello. Y aora declara que la receta de las cabezas de las ranas no está en el libro de Piamontes, si no en otro, que se intitula Tesoro de pobres» (f. 81r). 
Albert Toldrà i Vilardell. La caiguda de Felicià Piquer, bruixot processat per la Inquisició de València (1669-1673)

del concepte per sant Agustí, tota una tradició de la bruixeria, a partir del clàssic de Teòfil, en la Legenda aurea, fins a Faust. ${ }^{12}$ Jurídicament, la confessió o la provanza del pacte és important, perquè determinarà si hi ha hagut satanisme, és a dir, la qualitat del delicte comès. Interrogat finalment si creia en les coses que feia, respon que no, que «nunca dio crédito alguno de que suçedería lo que pretendía». Implícitament reconeix, doncs, que és un farsant. És clar que la credibilitat que podem atorgar a aquestes declaracions, d'un home empresonat a la Inquisició i sota l'amenaça de la tortura i la foguera, és molt relativa, detall que lamentablement molts historiadors han oblidat. Felicià signa la seua declaració, amb una lletra summament irregular i tremolosa.

Conclou llavors l'acusació: Felicià ha estat amonestat tres voltes pels inquisidors -el quadern que ens falta-i no ha confessat tota la veritat, sinó que ha estat «negativo y sumamente diminuto, de que se colige su obstinación y protervia», un agreujant. «Diminuto», és clar, vol dir que intenta reduir la gravetat dels seus crims. Per tant, el fiscal demana al tribunal que el declare culpable, mereixedor d'excomunicació major, i com a tal «se le condene en las mayores y más graves penas» previstes pel dret, i que «sea puesto a qüestión de tormento, en que esté y se le repita hasta que enteramente diga y confiese la verdad», les fórmules habituals en la pràctica inquisitorial.

El mateix dia 7 de novembre del 1671, en què ha tingut lloc aquesta densa audiència, Felicià és visitat a la vesprada per l’inquisidor González, excepcionalment, a la presó de familiars, una cambra a la planta baixa del palau de la Inquisició, una mena de presó «confortable» reservada als familiars del Sant Ofici. Felicià, però, no és en aquesta presó, sinó a les «comunes», «donde por enfermo y impedido estava». És aquesta la primera notícia del seu greu estat de salut: probablement no ha pogut pujar les escales fins a l'audiència. Tanmateix, l'acusat es nega a completar les seues declaracions $\prec$ Dixo que no tiene nada que decin», i l'inquisidor li assigna el que serà el seu advocat defensor, Francisco Juan Conca, seguint el protocol de la paròdia de la justícia inquisitorial (f. 82v.-83r.).

Fa la impressió que els inquisidors dilaten el procés, en espera de l'evolució de la malaltia de Felicià, per emetre la seua sentència quan estiga en condicions de suportar els assots i les galeres a què ja ha estat condemnat per la justícia reial, penes a les quals s'afegiran les del Sant Ofici. Però el reu no millora: el 4 de juliol del 1672 compareix, davant els inquisidors González i Casteldases, Miquel Jeroni Romà, el metge ordinari del Sant Ofici, per a dir que Felicià, al seu «aposento» o calabós, presenta darrerament un estat lamentable: "padeze diferentes achaques, como son distilación de la cabeza al pecho, con mucha toz, y de medio cuerpo como baldado con casi total impedimento para el movimiento, y con achaque de gota coral» (f. 83r.-82v.).

Uns dies després, el 18 de juliol, arriba des de Madrid la del liberació del Consejo de la Santa General Inquisición, el que es coneix per la Suprema, l'òrgan central del Sant Ofici, caracteritzat pel seu

12 La llegenda de Teòfil, en dues versions diferents, en Vorágine (1982: 574 i 854). La definició del pacte «expreso» segons el Tratado de las supersticiones y hechicerías (1529): «Con palabras claras e formales, renegando de la fe, hazen nueva profesión al demonio en su presencia (...) dándole entera obediencia y ofreciéndole su ánima y cuerpo» (Castañega 1994: IV). Vegeu també Alvarado (2005: 188-190).

SCRIPTA, Revista internacional de literatura $i$ cultura medieval i moderna, núm. 13 / juny 2019 / pp. 175-193 ISSN: 2340-4841 · doi:10.7203/SCRIPTA.13. 15480 
Albert Toldrà i Vilardell. La caiguda de Felicià Piquer, bruixot processat per la Inquisició de València (1669-1673)

centralisme $\mathrm{i}$ intervencionisme sobre processos i sentències. Condemnen Felicià a sortir al proper «auto de fe», vestit de manera infamant amb la samarreta, gramalleta o sanbenito, «con insignias de hechizero» -recordeu els gravats de Goya-, on serà llegit públicament el seu procés, abjurarà de levi -forma reservada als casos d'heretgia menys greus-, i després «se le den ducientos azotes», abans de ser desterrat de la ciutat de València per deu anys, dels quals els sis primers com a galeot. Signen els set membres de la Suprema i el secretari (f. 84r.). És a dir, que confirmen la condemna de la justícia reial, sense afegir-hi res. Acostumats a la inaudita crueltat de la Inquisició espanyola, no deixa de sorprendre'ns aquesta blanesa amb la bruixeria, fet que Caro Baroja remarca. ${ }^{13}$

Acompanyant la sentència i amb data de l'endemà, el 19 de juliol, una altra carta de la Suprema dóna instruccions als inquisidors de València: els tornen tant el procés inquisitorial com el de la justícia reial, els quals el tribunal havia remès a Madrid, els ordena que executen la sentencia i que retinguen el procés reial, «y que si la Justiçia Real pidiere el proçeso original que entregó y hiço contra este reo, responderéis no se le puede entregar por ser de materia y causa de fe» (f. 85r.). Les relacions entre totes dues justícies no eren gaire bones al País Valencià, des del mateix inici de la Inquisició (García 1976 i 2000).

El document que segueix és un altre informe, del 8 de novembre del 1672, dels metges ordinaris del Sant Ofici de València, Miquel Jeroni i Joan Baptista Bonet. Tots dos, «conformes», fan el diagnòstic de Felicià: ${ }^{14}$ el seu estat de salut és pèssim i no està en condicions «para tolerar ni llevar pena alguna corporal grabe» (f. 86r.). El 6 de desembre la Suprema contempla aquest informe mèdic: cal esperar i que «le vayan visitando los médicos» (f. 87r.). Els inquisidors es personen, el 22 de febrer del 1673, a les presons comunes, «en la cárcel donde está enfermo», per a l'acte de l'abjuració de Felicià, segurament en previsió de la seua propera mort i de la impossibilitat d'aplicar-li les penes sentenciades. Es tracta d'un full imprès emplenat, en què el reu reconeix la verdadera fe catòlica romana, i «abjuro, detesto y anathematizo toda especie de heregía» (f. 88r.).

El 17 de juny estrenem inquisidor: ja ho és l'anterior fiscal, Hermenegildo Ximénez; i Miquel Jeroni li presenta un altre preocupant informe sobre l'estat de Felicià. ${ }^{15}$ El pacient va empitjorant i ja se

13 «La Inquisición española, durísima con los judíos, inexorable con los protestantes, fue de una rara benignidad con la gente lanzada a actividades mágicas, y la irrealidad de cantidad de acusaciones se halla implícitamente admitida en la pena impuesta» (Caro 1992: I, 30). Als exemples de víctimes del rigor del Sant Ofici que posa Caro, caldria afegir-hi els moriscs i els homosexuals. Un altre col lectiu de processats beneficiari de la indulgència inquisitorial és el dels sacerdots sol licitadors (Toldrà 2017).

14 «padece varios achaques, y entre otros una alferecía y una destilación de la cabeça al pecho, ocasionándole algunas veces a echar sangre por la voca, y un encojimiento de nervios en la pierna y en el braço izquierdo, y juntamente una extenuaçión de todo el cuerpo, qu está impedido del movimiento para tenerse en pie, no pudiendo andar sin muletas y con mucha dificultad» (f.86r.).

15 «de muchos achaques que tiene y padeze, y en particular de una perlesía en el lado izquierdo, quitándole y privándole de todo movimiento (...) y de una destilación que le cae de la cabeza al pecho, ocasionándole una asma y dificultad para respirar, con mucha toz, traiéndole a puntos de ahogarse y sufocarse, y caiéndole parte d'ella en muchas ocasiones al

SCRIPTA, Revista internacional de literatura i cultura medieval i moderna, núm. 13 / juny 2019 / pp. 175-193 ISSN: 2340-4841 · doi:10.7203/SCRIPTA.13. 15480 
Albert Toldrà i Vilardell. La caiguda de Felicià Piquer, bruixot processat per la Inquisició de València (1669-1673)

li ha administrat el viàtic en tres ocasions i l'extrema unció en una; «y si no fuera por el cuydado y asistencia que se ha tenido con él, este por infalible fuera muerto». Dictamina el metge que Felicià ja no serà capaç de sostenir «pena alguna corporal»; més aviat «está este rezeloso se halle muerto quando menos se lo piensen» (f. 89r.-89v.). En efecte, el 5 de juliol Ambrosio Castelló, l'alcaid, es presenta a l'audiència, «a las ocho horas», per informar el nou inquisidor que un moment abans, en entrar al calabós de Felicià, l'havia trobat mort. L'inquisidor envia immediatament Ambrosio a l'Hospital General per a que «esta tarde, entre una y dos, que es hora cauta, viniessen por dicho cadáver». La Inquisició sempre tan discreta i cautelosa: saben que la tafanera ciutat de València sentirà una enorme curiositat per saber qui és el mort que trauen de les presons del Sant Ofici (f. 90r.).

Felicià és mort, però el procés encara s'allarga. El mateix dia de la seua mort, «a las dos horas y media de la tarde», l'alcaid informa l'inquisidor que ha lliurat a Dionís Claver, enviat de l'hospital, el cadàver del bruixot. Posat en un carro, el cos és cobert amb estores i portat a soterrar al cementeri de l'Hospital General (f. 90r.). I irònicament, del mateix 5 de juliol és la data de la carta de la Suprema (rebuda a València el dia 22) en què, vist l'estat de Felicià, ordena que «le pongáis, señores, en el ospital» (f. 92.). L'endemà l'inquisidor Ximénez cita a declarar Úrsula Anna Sanchis, la dona que des de fa dos anys atenia Felicià a la presó «de orden de este tribunal», i qui el va trobar mort. Conta com la vespra li havia portat un parell d'ous, i no li va semblar més malalt que altres dies; l'endemà al matí, però, a primera hora va entrar al seu calabós amb l'alcaid i, en saludar-lo i veure que no contestava, el tocaren «y vieron que estaba muerto» (f. 91r.-v.).

Al darrer document de la sumària, que és una carta enviada per la Suprema el 2 de septembre del 1673, amb registre d'entrada del dia 11, responent una demanda dels inquisidors de València, se'ls dóna instruccions sobre l'afer: «en caso que la justiçia real os pida la persona del dicho Feliciano Piquer, digáis de palabra que en el Ospital General le darán razón d'él, según avéis entendido, y no le daréis testimonio ni otra raçón» (f. 93r.). Bon exemple del tarannà amable del Sant Ofici.

Hem vist una mostra d'una realitat social abundant a l'Antic Règim: el sacatesoros, un bruixot a mig camí entre la superstició popular i la nigromància culta, que sense escrúpols fa servir les seues martingales màgiques per treure'n algun profit, en aquest cas sexual, fet que al capdavall provoca la seua caiguda. Tot plegat, allò és possible gràcies a la increible credulitat de tots els implicats -inclòs fins i tot un frare-, en contrast amb l'aparent racionalitat dels inquisidors, que, pel tracte que li donen, evidentment consideren Felicià un farsant. Ho és? Fins a quin punt? En algunes de les seues esperpèntiques diligencias no obté cap benefici, ni sexual ni molt menys econòmic; i fa l'efecte que ell mateix es creu, com les seues víctimes, les seues pròpies fantasies -l'imaginari màgic.

estómago, causándole muchos vómitos, y de una epilepsia o alferecía que le toma casi todas las noches, privándole del todo de todos los sentidos (...) y de un dolor agudo que de continuo tiene en la parte del vaso» (f. 89r.).

SCRIPTA, Revista internacional de literatura i cultura medieval i moderna, núm. 13 / juny 2019 / pp. 175-193 ISSN: 2340-4841 · doi:10.7203/SCRIPTA.13. 15480 
Albert Toldrà i Vilardell. La caiguda de Felicià Piquer, bruixot processat per la Inquisició de València (1669-1673)

\section{Bibliografia}

Alvarado Planas, J. (2005) «Un contrato herético: el pacto con el diablo», dins Escudero, J. A. Intolerancia e Inquisición, Sociedad Estatal de Conmemoraciones Culturales, 2005, vol. II., pp. 181206.

Amelang, J. S. (2004) «Durmiendo con el Enemigo: el diablo en los sueños», dins Tausiet, M. i Amelang, J. S. (eds.) El diablo en la Edad Moderna, Madrid, Marcial Pons, pp. 327-355.

Ardit, M. (1970) La Inquisició al País Valencià, València, 3 i 4.

Bologne, J.-C. (1993) Du flambeau au bûcher. Magie et superstition au Moyen Âge, París, Plon.

Boscà Codina, J. V. (1991) «Sortílegas, adivinas y conjuradoras: indicios de una religiosidad prohibida», Revista d'Història Medieval, $n^{\circ}$ 2. pp. 63-76.

Caro Baroja, J. (1982) Brujería vasca, Donostia, Txertoa.

—. (1992) Vidas mágicas e Inquisición, Madrid, Istmo, vol. I.

—_. (1993) Las brujas y su mundo, Madrid, Alianza Editorial.

—. (1994) El señor inquisidor, Madrid, Alianza Editorial.

Castañega, Martín de (1994) Tratado de las supersticiones y hechicerías y de la possibilidad y remedio dellas (1529), Ed. J. R. Muro Abad, Logronyo, Instituto de Estudios Riojanos.

Cátedra García, P. M. (1994) Sermón, sociedady literatura en la Edad Media. San Vicente Ferrer en Castilla (1411-1412). Estudio bibliográfico, literario y edición de los textos inéditos, Salamanca, Consejería de Cultura y Turismo de la Junta de Castilla y León.

Conde, A. (2003) «Sorcellerie et Inquisition au XVIe siècle en Espgne. L'exemple du diocèse de Cuenca. L'inquisiteur Ruesta face à la Suprema: entre mythe et réalité», dins Molinié, A. \& Duviols, J. P. (dirs.) Inquisition d'Espagne, París, Presses Universitaires de Paris-Sorbonne, pp. 95-108.

De Prado Mora, Á. (2003) El Tribunal de la Inquisición en España (1478-1834), Madrid, Editorial Actas.

Foucault, M. (1975) Surveiller et punir. Naissance de la prison, París, Gallimard.

—. (1992) La verdad y las formas jurídicas. Barcelona, Gedisa.

García Cárcel, R. (1976) Orígenes de la Inquisición española. El tribunal de València, 1470-1530, Barcelona, Edicions 62.

—. (1979) Herejía y sociedad en el siglo XVI. La Inquisición en Valencia 1530-1609, Barcelona, Edicions 62.

García Cárcel \& Moreno Martínez, D. (2000) Inquisición. Historia Crítica, Madrid, Temas de Hoy.

Gimeno Blay, F. M. \& Mandingorra Llavata, M. L. (2009) Sermones de Cuaresma en Suiza, 1404 (Couvent des Cordeliers, ms. 62), València, Ajuntament de València.

Ginzburg, C. (1966) I Benandanti. Stregoneria e culti agrari tra Cinquecento e Seicento, Torino, Giulio Einaudi. 
Albert Toldrà i Vilardell. La caiguda de Felicià Piquer, bruixot processat per la Inquisició de València (1669-1673)

Haliczer, S. (1993) Inquisición y sociedad en el Reino de Valencia 1478-1834, València, Edicions Alfons el Magnànim, Generalitat Valenciana i Diputació de València.

Kamen, H. (1984) «Notas sobre brujería y sexualidad y la Inquisición», dins Alcalá, Á. (dir.) Inquisición española y mentalidad inquisitorial, Barcelona, Ariel, pp. 26-36.

—. (1999) La Inquisición española: una revisión histórica, Barcelona, Crítica.

Kieckhefer, R. (1991) «Erotic Magic in Medieval Europe», dins Salisbury, J. E. (ed.), Sex in the Middle Ages, Garland, New York.

- (1992) La magia en la Edad Media, Barcelona, Crítica.

Klaniczay, G., \& Kristóf, I. (2001) «Écritures saintes et pactes diaboliques. Les usages réligieux de l'écrit (Moyen Age et Temps modernes) », Annales n 5, pp. 947-981.

Knutsent, G. W. (2009) Servants of Satan and Masters ofDemons: the Spanish Inquisition's Trials for Superstition, Valencia and Barcelona, 1478-1700, Brepols Publishers.

Lacarrière, J. (ed.) (2000) Evangelios de las ruecas, Palma de Mallorca, José de Olañeta.

Lisón Tolosana, C. (1990) Demonios y exorcismos en los siglos de oro, Madrid, Akal.

Martínez Bujanda, J. (1984) «Índices de libros prohibidos del siglo XVI», dins Historia de la Inquisición en España y América, Madrid, BAC (3 vol.).

Martínez Millán, J. (2007) La Inquisición española, Madrid, Alianza Editorial.

Pardo Tomás, J. (2004) «Diablos y diabluras en la literatura de secretos», dins Tausiet, M. \& Amelang, J. S. (eds.) El diablo en la Edad Moderna, Madrid, Marcial Pons, pp. 297-325.

Ryley Scott, G. (2006) Storia delle punizioni corporali, Milano, Mondadori.

Sánchez Lora, J. L. (2003) «Claves mágicas de la religiosidad barroca», dins La religiosidad popular. Vol. II, Vida y muerte: la imaginación religiosa, Barcelona, Anthropos, pp. 125-145.

Schmitt, J.-C. (1992) Historia de la superstición, Barcelona, Crítica.

Toldrà i Vilardell, A. (2011) En nom de Déu. La Inquisició i les seues víctimes al País Valencià, Picanya, El Bullent.

- (2017) Per la reixeta. Sol licitació sexual en confessió davant la Inquisició de València (1651-1819), València, Universitat de València.

Torquemada, M. J. (2000) La Inquisición y el diablo. Supersticiones en el siglo XVIII, Sevilla, Universidad de Sevilla.

Varazze, Iacopo de (1480) Legenda Aurea, Venècia, P. Strata de Cremona i M. Catanello Schaluicola. . (1977) Vides de sants rosselloneses. Text català del s. XIII, Ed. Kniazzeh, C. H. S. M., \& Neugard, E. J. \& Coromines, J., Barcelona, Fundació Salvador Vives Casajoana.

Vorágine, Santiago de la (1982) La leyenda dorada, Madrid, Alianza Editorial, 2 vol. 